\title{
MOVERS
}

\section{Klaus Stöhr, director of the influenza vaccine franchises, Novartis Vaccines and Diagnostics, Cambridge, Massachusetts}

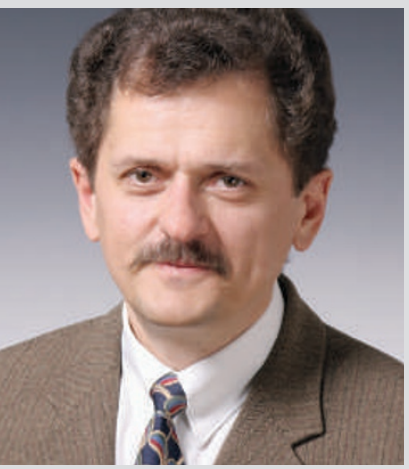

2006-07: Senior adviser, Influenza Pandemic Vaccine Development, World Health Organization (WHO), Geneva, Switzerland 2001-06: Coordinator, WHO Global Influenza Programme, Geneva, Switzerland 2003: Coordinator, SARS aetiology and diagnosis, WHO, Geneva, Switzerland

Many graduate students tackle complex research problems. Rarely, however, does a PhD dissertation help to craft a capable international response to a pandemic. Klaus Stöhr's did. Having previously secured his veterinary medicine degree at the University of Leipzig in what was then East Germany, Stöhr continued for a PhD focused on developing processes and procedures necessary to detect and identify the sources of emerging diseases in good time.

His thorough, proactive work soon landed him a position as director of a rabies vaccine development programme at the National Institute for Epidemiology and Infectious Disease Control in Animals. It would be the first of many projects capitalizing on his attention to detail and planning.

Leaders of the World Health Organization (WHO) took notice, and Stöhr accepted a job there in 1991. His initial work on rabies led to efforts focused on foodborne diseases, then antimicrobial resistance.

By 2000 , he was charged with revitalizing the WHO influenza programme. Within two years, the programme reached a level of international recognition. David Heymann, the WHO's executive director for communicable diseases, credits Stöhr with not only developing the first WHO pandemic plan for influenza, but also building a cohesive network of cooperating laboratories around the world that could monitor for influenza and communicate rapidly. Indeed, Stöhr's existing network pinpointed the SARS corona virus in record time - four weeks after it first emerged in 2003. He went on to work with nations to develop global surveillance and laboratory methods, and he advised the pharmaceutical industry to help it transform the correct vaccine strains into vaccines. He has since been leading the WHO's response to avian influenza.

This year, after 15 years at the WHO, Stöhr has made what some may think is a surprising move. With offers on the table from the Harvard School of Public Health and several companies, he accepted a post as director of the influenza vaccine franchises at Novartis Vaccines and Diagnostics. He will focus on the business of vaccine development - the aspect of public health he found most challenging.

"In the public-health arena, there is not a good understanding of working with 'pharma', which is why I want to understand it better," says Stöhr.

Industry, says Heymann, is lucky to have Stöhr - whose excellent understanding of the basic science is only surpassed by his tireless efforts in public health. Virginia Gewin
NETWORKS \& SUPPORT

\section{Gem of an idea for a unique machine}

As summer approaches, universities across the globe will begin assembling teams of talented undergraduates from diverse disciplines to participate in the annual international genetically engineered machine (iGEM)

competition. The contest tries to spark advancements in synthetic biology by encouraging research teams to design and construct new, unique genetic devices based on biological cells and circuits. The students, along with faculty members and graduate student mentors, are asked a simple question: "What would you like to

The iGEM team at the University of Texas, Austin, for example, engineered Escherichia coli to sense and respond to light in a novel way, enabling the construction of a bacteria-based photo-printing system (see Nature 438, 441-442; 2005).

This year the Harvard iGEM team will consist of about a dozen students, mentored by faculty members, postdocs and graduate advisers. It is a rare opportunity for undergraduates to learn from and interact with a host of colleagues who are all interested in fostering the students' excitement for science and research.

Unlike traditional courses, the iGEM platform gives undergraduates much more freedom in the design, build this summer?" direction and implementation of their projects, and helps build essential skills for team work. Students are encouraged to brainstorm and to propose ideas and experiments to pursue during the summer. These sessions not only build team spirit but also help the students to start thinking critically about how research is really done, from the initial idea to the experimental design.

Students work together throughout the summer. Then in November, teams from across the world come together to present and celebrate their work at the annual iGEM jamboree. Some projects inspire further development by future iGEM teams; others also play an important role by contributing directly to projects that postdocs and graduate students are working on.

The iGEM competition has been growing rapidly since it was launched in 2004, starting with 5 teams in 2004, 13 teams in 2005, and 37 teams in 2006. This year, it is estimated that 80 to 100 teams will participate. We encourage other universities to join us and use this unique platform for research and education.

Michael Strong is a Harvard Medical School postdoc and an iGEM teaching fellow. George Church is a Harvard Medical School professor of genetics and an iGEM faculty adviser.

\section{POSTDOC JOURNAL}

\section{The balancing act}

Recently, within the space of six weeks, I did a presentation at a department seminar, prepared a lab meeting, submitted an abstract for a scientific workshop, underwent the semi-annual review of my external funding, networked at a careerdevelopment event, conducted experiments for my project, drafted a manuscript for submission and, to top it all off, proofread both the primary data paper and the book chapter that my husband, also a postdoc, is writing.

Then, of course, there were personal matters to attend to, such as our imminently expiring apartment lease and potential homelessness.

At times like these, when my hours are long and my 'to do' lists even longer, I'm tempted to join the circus. After all, postdocs are expert jugglers: we constantly have multiple experiments, responsibilities and commitments up in the air. We are agile tightrope walkers: from start to finish, we have to balance our professional goals with our mentor's expectations, our family obligations and our personal priorities, sometimes without a safety net. We're capable contortionists: we demonstrate remarkable flexibility when put in a tight spot. Sometimes we're lion tamers, winning the cooperation and respect of those who can be notoriously challenging to work with. Most of all, we're dedicated performers. We know, always, that the show must go on.

Maria Thelma Ocampo-Hafalla is a research fellow at Cancer Research UK's London Research Institute. 